\title{
The Dimension of Food Souvenir: An Exploratory-Confirmatory Factor Analysis
}

\author{
Adila Sosianika ${ }^{1}$, Tintin Suhaeni ${ }^{1}$, Nono wibisono ${ }^{1}$, and Dwi Suhartanto ${ }^{1 *}$ \\ ${ }^{1}$ Department of Business Administration, Politeknik Negeri Bandung, Indonesia
}

\begin{abstract}
Food souvenirs as the tangible reminder that encounters the travelling experience are considered as an essential element in the tourism industry. However, the studies exploring the dimension of food souvenirs, are limited, and most of them applying single factor analysis, either exploratory or confirmatory. In response to the identified gap, this research scrutinizes the aspects of food souvenirs by utilizing a mixed method of exploratoryconfirmatory factor analysis. The data was collected from 252 domestic tourists in Bandung, Indonesia. The exploratory factor analysis test identifies four dimensions of food souvenirs: tangible, brand and packaging, value, food quality. Although confirming the food souvenir dimension, the confirmatory factor analysis notes that the elements of the dimensions are different from that identified in exploratory factor analysis. Besides offering a theoretical understanding on the food souvenirs dimension, this study extends our understanding of a methodological issue that the exploratory-confirmatory factor analysis offers a better explanation on the food souvenir dimension compared to that of single factor analysis.
\end{abstract}

\section{Introduction}

A souvenir is a tangible product that encounters the perceptual images of travelling experience and its effects on a favourable tourist future behaviour. Many tourists feel that they need a souvenir in their travelling to keep their unforgettable experience and also to complete their trips [1, 2]. A souvenir might even have a social function [3]. By sharing and giving of souvenirs to their families, friends, and colleagues, the travellers might have values of self-esteem, prestige, and pride. Moreover, a souvenir also can give unforgettable retention of the cultural value of the destination visited. Thus, a souvenir consider as an essential element for the tourism industry since it has a good impact not only on the industry but also for the economy of the destination $[4,5]$. As a result of its essential role in the tourism industry, souvenirs have been studied from different perspectives, including cultural, behavioural, and retailing $[4,6,7]$.

The recent studies have considered the food which a tourist bought in a tourist destination as an important souvenir [2,7]]. Food souvenirs, mainly local delicacies and specialty foods, are recognized as a tangible product to capture the unique nature of the destination. Therefore, travellers buy a particular food to enjoy physically and mentally and relate its identity to the destination visited [3]]. Food souvenirs also consider as an important aspect on the development of economic, other industries, such as agriculture,

\footnotetext{
* Corresponding author: dwi.suhartanto@polban.ac.id
} 
dairy, and fishery [8]] as well as cultural and environmental sustainability of the tourist destination $[9,10]]$. However, the role of food souvenir and its essential meaning in the tourism industry, especially the study exploring the dimension of food souvenirs, are still limited in the literature. Moreover, previous studies assessing the dimension of food souvenirs mostly use exploratory factor analysis or confirmatory analysis only $[3,5,11]$. The usage of a single factor analysis very often provides different findings [12]]. Thus, using a single factor analysis approach to assess the dimension of food souvenir could potentially result in un-comprehensive dimension. This study argues that exploring the dimension of food souvenirs using a mixed method, exploratory-confirmatory factor analysis, will provide a better result.

Based on the research gap identified, this research aims to scrutinize the dimension of food souvenir by applying an exploratory-confirmatory factor analysis approach. In the competitive tourism industry, understanding the dimension of food souvenirs is critical for both retail managers as well as tourism destination managers to develop a proper marketing strategy to satisfy tourists' need of food souvenir.

\section{Literature review}

A souvenir is a tangible object and intangible memorable experience for tourists during and after their travelling [1,6]]. Past studies categorize souvenirs into three types: local products, products distinct with graphics, and outfits and jeweller [[13]]. The researchers have also identified local food and beverage products in some countries that are related to cultural tourism, such as candy, alcohols, spices, and tea souvenirs [10]. Food souvenir is considered as a tool to express the local culture as well as assign tourists with a unique culture and way of life of the residents [14]].

Recently, researchers classify the local food as a souvenir and suggest its critical role in improving the competitive advantage of a tourist destination [15]]. Although there are many studies conducted on local food as a souvenir, previous research focusing on the dimension of food souvenirs is limited [3, 8]. A survey in Chinese tourism identifies four dimensions of food souvenir, i.e. quality, symbol, innovation, and practicality [8]. Altintzoglou et al. [9]' study on Norway food souvenirs and tourist innovativeness propose the key elements affecting travellers in selecting and purchasing food as souvenirs, including taste, quality, authenticity and local origin. Suhartanto $[6,16]]$ report five dimensions of food souvenirs in the Indonesian domestic tourist context, namely value, store, collectability, display, and functionality. A different result is indicated by Paraskevaidis and Andriotis [17]] who identify exchange value, use value, spiritual value, and sign value as the dimension of food souvenir.

To sum up, the previous literature has indicated a significant growth in understanding souvenirs as an element of a tourism destination's contributor. Recently, researchers have also reported the critical role of food souvenirs in influencing tourist buying decisions as well as highlighting the local tourist destination values and community creativities. Much of past researchers tend to emphasize on the meaning of food as a souvenir, but limited attention has been given on the dimensionality of food as a souvenir.

\section{Method}

The measurement of food souvenirs scales in this research was drawn from the previous literature on souvenir and specialty food $[3,8,9]$ (see table1). All variable elements were anchored using a 5-point Likert's scale (from 1 strongly disagree to 5 strongly agree). SelfAdministrated questionnaires were distributed to 252 tourists. This number of data is 
considered as adequate to test the dimension of food souvenir using both exploratory and confirmatory factor analysis $[12,18]$. The respondents consist of females $(39.68 \%)$, and males $(60.32 \%)$ with the majority $(48.02 \%)$ were at the age of $17-25$ years. The data was gathered from tourists who visited Bandung City. To obtain a robust data, the respondents were approached after buying a food souvenir. As it is impossible to use random sampling, the purposive sampling method was applied. To test the proposed model of food souvenir, this sampling method is considered as appropriate [19]. To examine the dimension of food souvenirs, this study uses the mixing method of exploratory-confirmatory factor analysis approach. The confirmatory factor analysis was executed by applying Structural Equation Modelling (SEM) as suggested by scholars $[12,18]$.

\section{Result}

To scrutinize the dimensions of food souvenirs, an exploratory factor analysis (EFA) was conducted with the 12 items to measure tourist perception of a food souvenir. This study utilizes principal component analysis as a method of extraction and a varimax rotation with Kaiser normalization as recommended by past researchers [18] for a parsimonious description of the dimensions.

Table 1. Rotated Component Matrix

\begin{tabular}{|l|l|l|l|l|}
\hline \multirow{2}{*}{\multicolumn{1}{|c|}{ Items }} & \multicolumn{4}{c|}{ Component } \\
\cline { 2 - 5 } & Tangible & $\begin{array}{c}\text { Packaging } \\
\text { an Brand }\end{array}$ & Value & $\begin{array}{c}\text { Food } \\
\text { Quality }\end{array}$ \\
\hline 1. Taste & .098 & -.123 & .389 & .515 \\
\hline 2. Natural & .084 & .145 & -.017 & .789 \\
\hline 3.Healthy food & .210 & .313 & .034 & .702 \\
\hline 4. Interesting food display & .085 & .821 & -.038 & .264 \\
\hline 5. Good packaging design & .244 & .752 & .102 & .199 \\
\hline 6. Practical & .695 & .123 & .035 & .209 \\
\hline 7. Eco-friendly & .772 & -.027 & .132 & .240 \\
\hline 8.Value product & .103 & -.015 & .820 & .146 \\
\hline 9.Reasonable price & .029 & .174 & .866 & .006 \\
\hline 10.Brand memorable & .277 & .494 & .425 & -.153 \\
\hline 11.Interesting packaging & .612 & .479 & .144 & -.159 \\
\hline 12.Trusted producer & .613 & .261 & .029 & .034 \\
\hline
\end{tabular}

The result (Table 1) exposes the 12 items can be grouped into four factors covering $62.316 \%$ of the variance. All of the four dimensions identified have Cronbach's Alphas above 0.70 , specifying the reliability of the identified dimensions[18]. The result of KaiserMeyer-Olkin test (0.754) and Bartlett's test of sphericity $(\mathrm{p}<0.01)$ support for the sampling adequacy and convergent validity of the instruments. Further, the results suggest that the variance of the original values is relatively supported by the common factors as indicated by their commonalities; ranging from 0.441 to 0.781 . The construct discriminant validity is satisfied with factor loadings exceeding the cut-off value of 0.5 [18].

As exposed in Table 1, the exploratory factor analysis extracts four underlying factors of the food souvenir. The first factor consists of four items (with eigenvalue 3.63) and 
explains $17.044 \%$ of the variance, namely practical, eco-friendly, interesting packaging and trusted producer. Thus, the first factor is labelled as Tangible. The second factor consists of three items (with eigenvalue 1.512) which explain $16.352 \%$ of the variance of the data. This factor is loaded with the item of interesting food display, good packaging design, and brand memorize able. So, this factor is labelled as Packaging and Brand.

The third factor consists of two items (eigenvalue 1.316) and accounts for $15.070 \%$ of the variance. The third factor is loaded with items of value product and reasonable price; thus it is labelled as Value. The fourth factor contains three elements (with eigenvalue value 1.20) explains $13.849 \%$ of the variance. The three items connected with this factor consist

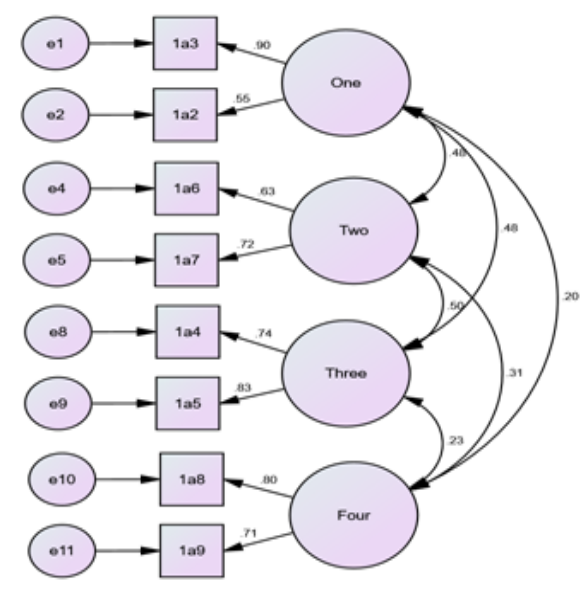

Fig. 1. The modified model of taste, natural and healthy food; so this factor is labelled Food Quality[20].

The measurement of food souvenirs model was assessed using confirmatory factor analysis (CFA), where the dimensions of food quality were supposed to co-vary with one another. The outcome of CFA test indicates that the goodness-of-fit index of the model (CMIN/DF: 5.390, GFI: 0.920, CFI: 0.846, and RMSEA: 0.096) identified is inadequate level of model fit. To increase the level of model fitness, the adjustment of the food souvenir attributes was directed by reparameterizing the model on the basis of the insignificant path, standardized residuals, modification index value, and hypothetical considerations [21-23]. Using this process (Table 2 and Figure 1 ), the best food souvenir dimension consists four dimensions with each consist of two items. The exclusion of item 1a1 (Dimension One), 1a11 and 1a12 (Dimension Two), and item 1a10 (Dimension Three) did not considerably modify the hypothesized content of the construct. The reason was the remaining items had a robust statistical similarity and theoretically consistent with each dimension.

The result of modifying the CFA test exhibited that the goodness-of-fit indexes of the model (CMIN/DF: 4.109, GFI: 0.970, CFI: 0.951, and RMSEA: 0.081) specifies an excellent of model fit. Further, Table 2 indicates that the values of the composite reliability of all four dimensions are higher than 0.7 and the values of average variance extracted are also higher than 0.5 [5].

Table 2: Reliability and Validity Check

\begin{tabular}{|l|c|c|l|l|l|l|}
\hline \multicolumn{1}{|c|}{ Variable } & CR & AVE & Tangible & $\begin{array}{c}\text { Brand \& } \\
\text { Packaging }\end{array}$ & Value & $\begin{array}{c}\text { Food } \\
\text { Quality }\end{array}$ \\
\hline Tangible & 0.626 & 0.501 & $\mathbf{0 . 6 7 6}$ & & & \\
\hline Brand \& Packaging & 0.759 & 0.613 & 0.502 & $\mathbf{0 . 7 8 3}$ & & \\
\hline Value & 0.730 & 0.575 & 0.314 & 0.232 & $\mathbf{0 . 7 5 8}$ & \\
\hline Food Quality & 0.707 & 0.560 & 0.482 & 0.484 & 0.205 & $\mathbf{0 . 7 4 9}$ \\
\hline
\end{tabular}

Additionally, the requirement for discriminant validity is also met as average variance values extracted are higher than the constructs formed correlation[5]. Thus, the requirement 
of construct reliability and validity is satisfied. The finding of this research indicates that tangible aspect is a critical element of food souvenir. Thus, this study suggests the souvenir retail managers need to consider the tangible attributes of the food, including practicality, environmentally friendly, attractive packaging, and a good producer image ${ }^{[6,10]}$. Besides, this study also suggests the usage of a unique brand as well as interesting packaging design to attract tourist to buy food souvenir[20]. Moreover, consistent with previous studies[6, 7], the result of this study indicates that value and price are important elements of food souvenirs. Finally, this study highlights the food quality as an essential attribute of food souvenir. It suggests that the food souvenir should meet with the food health standard[8], have a good taste, and contain natural ingredients.

From the methodological perspective, this study shows that although the dimensions identified in exploratory, as well as confirmatory factor analysis, are similar, the items are different. Thus, this research gives a new perspective that examining the dimensionality of food souvenir, as well as another souvenir, should use exploratory-confirmatory factor analysis rather than only a single factor analysis. This finding is important as none of past studies has discussed such issue in food souvenir context.

\section{Conclusion, Implication, and Future Research}

The previous scholars have examined the dimension of food souvenir, but they are only applying exploratory factor analysis or confirmatory factor analysis. Thus, their results are considered as less robust. This study focuses on the usage of exploratory-confirmatory factor analysis to identify the dimension of food as a souvenir. The results show that this method identifies four dimensions of food souvenirs, but the elements of the dimensions are different. Besides offering useful implications for understanding tourist behaviours towards the food souvenir, this study extends our understanding that in assessing the dimension of food souvenir researchers should use both factor analysis instead of only a single factor analysis. Although this study offers significant findings, this study bears drawback concerning the sample which is collected in Bandung. As a result, this study cannot be generalized in other location. Thus, the future research could replicate this study in a different location, culture, and souvenir type.

\section{References}

1. W. H. Kong and T. Z. Chang, "The Role of Souvenir Shopping in a Diversified Macau Destination Portfolio," Journal of Hospitality Marketing and Management, 21, pp. 357-373 (2012)

2. K. K. Swanson and D. J. Timothy, "Souvenirs: Icons of meaning, commercialization, and commoditization," Tourism Management, 33, pp. 489-499 (2012)

3. L. Lin and P. C. Mao, "Food for memories and culture - A content analysis study of food specialties and souvenirs," Journal of Hospitality and Tourism Management, 22, pp. 19-29 (2015)

4. C. Tosun, P. Temizkan, D. Timothy, and A. Fyall, "Tourist shopping experience and satisfaction," International Journal of Tourism Research, 9, pp. 87-102 (2007)

5. D. Suhartanto, D. Dean, A. Sosianika, and T. Suhaeni, "Food souvenirs and their influence on tourist satisfaction and behavioral intentions," European Journal of Tourism Research, 18, pp. 133-145 (2018)

6. D. Suhartanto, "Tourist satisfaction with souvenir shopping: evidence from Indonesian domestic tourists," Current Issue in Tourism, 21, pp. 663-679 (2018). 
7. D. Suhartanto, D. Dean, R. Nansuri, and N. N. Triyuni, "The link between tourism involvement and service performance: Evidence from frontline retail employees," Journal of Business Research, 83, pp. 130-137 (2018)

8. L. Lin, "Food souvenirs as gifts: tourist perspectives and their motivational basis in Chinese culture," Journal of Tourism and Cultural Change, pp. 1-16 (2016)

9. T. Altintzoglou, M. Heide, and T. Borch, "Food souvenirs: Buying behavior of tourists in Norway," British Food Journal, 118, pp. 119-131 (2016)

10. K. Buczkowska, "Local food and beverage products as important tourist souvenirs," Turystyka Kulturowa, 1, pp. 47-58 (2014)

11. D. Suhartanto, B. T. Chen, Z. Mohi, and A. Sosianika, "Exploring loyalty to specialty foods among tourists and residents," British Food Journal, 120, pp. 1120-1131 (2018)

12. [12] J. E. Hair, G. T. Hult, C. M. Ringle, and M. Sarstedt, A Primer on Partial Least Squares Structural Equation Modeling (PLS-SEM), 2nd ed. Thousand Oaks: Sage (2017)

13. H. Wilkins, "Souvenirs: What and why we buy," Journal of Travel Research, 50, pp. 239-247, (2011)

14. H.-W. Joung, E.-K. Choi, and E. Wang, "Effects of Perceived Quality and Perceived Value of Campus Foodservice on Customer Satisfaction: Moderating Role of Gender," Journal of Quality Assurance in Hospitality \& Tourism, 17, pp. 101-113 (2016)

15. T. T. Trinh, C. Ryan, and J. Cave, "Souvenir sellers and perceptions of authenticity The retailers of Hội An, Vietnam," Tourism Management, 45, pp. 275-283 (2014)

16. D. Suhartanto, "The role of store coopetition and attractiveness on the performance of tourism destination and its retail stores," International Journal of Tourism Policy, 7, pp. 151-165 (2017)

17. P. Paraskevaidis and K. Andriotis, "Values of souvenirs as commodities," Tourism Management, 48, pp. 1-10 (2015)

18. [18] J. F. Hair, W. C. Black, B. J. Babin, and R. E. Anderson, Multivariate data analysis: A global perspective, 7th ed. Upper Saddle River: Pearson Education (2010)

19. N. L. Reynolds, A. C. Simintiras, and A. Diamantopoulos, "Theoretical justification of sampling choices in international marketing research: Key issues and guidelines for researchers," Journal of International Business Studies, 34, p. 80-95 (2003)

20. S. Mynttinen, L. Logren, M. Sarkka-Tirkkonen, and T. Rautiainen, "Perceptions of food and its locality among Russian tourists in the South Savo region of Finland," Tourism Management, 48, pp. 455-466 (2015)

21. J. C. Anderson and D. W. Gerbing, "Structural equation modeling in practice: A review and recommended two-step approach," Psychological Bulletin, 103, p. 411423) (1988)

22. P. M. Bentler and C.-P. Chou, "Practical issues in structural modeling," Sociological Methods \& Research, 16 (1987)

23. J. C. Anderson and D. W. Gerbing, "Structural equation modeling in practice: A review and recommended two-step approach," Psychological Bulletin, 103, pp. 411423 (1988) 